los dos músicos de ficción es que también recuerdan a otros de la realidad sin forzar mucho la imaginación.

\title{
LA ACULTURACIÓN
}

Toda reseña de La balada resultará incompleta si no se aborda una de las preocupaciones fundamentales que el autor vuelca en su nouvelle: la alienación. Los individuos viven una realidad construida a partir de los medios masivos. Sin ir muy lejos, el nexo entre Sosa y Barkley es una radio a transistores y la AM local.

Tal es el grado de exposición del protagonista a los medios masivos, que inventa un idioma que se asemeja al inglés aunque se construye sobre una base de fonemas de lengua hispana. Así por ejemplo, la novela se inicia con un acápite del blues Melancolía sobre tus rodillas, cuya representación escrita de la versión de Sosa, es: I nid tubí frí/ uit iú ander de tri/ Bat aiam an only blak man/an ... pur beiby."

La radio no es el único medio que está presente en la cotidianidad de Mosquitos, no hay que olvidar al D'Aguerre. A lo largo de la novela, la realidad será entendida a través de categorías mentales forjadas a través de años de matinée. Quizás haya ciertos puntos de contacto por este tema entre Mario Delgado y Manuel Puig.

Mario Delgado nació en Florida, 1949. Integró la antología Los más jóvenes cuentan (Arca, 1976) y luego publicó en Ediciones de la Banda Oriental, Causa de buena muerte (1982), Estado de gracia (1983), El día de la cometa (1985), La balada de Johnny Sosa (1987) y más recientemente, La llave de Francia (1991).

HÉCTOR GARCIA

EDUARDO GALEANO, Memoria del fuego. México/Madrid: Siglo XXI Editores, S. A. I- Los nacimientos, $1^{\mathrm{a}}$ Edición, 1982; II - Las caras y las máscaras, $1^{\mathrm{a}}$ Edición, 1984; III - El siglo del viento, 1를 Edición, 1986.

\section{HISTORIOLOGIA POETICA:}

Memoria del fuego cuenta el pasado de América en 1300 secuencias, a través de un lenguaje hondamente poético. El autor invierte la perspectiva desde la cual suele escribirse la historia. La historiografía tradicional presenta la evolución de las sociedades como una sucesión ajena, por cerrada eindiscutible, de mandatarios, períodos de crisis, revoluciones, guerras. Para ello usa un lenguaje "científico", pretendidamente objetivo, predominantemente abstracto. El lector americano debe aceptar con resignación la historia "oficial"1 de su

1 Eduardo Galeano, "Apuntes sobre la memoria y sobre el fuego", en Brecha (Montevideo, 20 de abril de 1990). 
continente, en la cual poco o nada figuran los americanos que no descienden del conquistador europeo o sus sucedáneos americanos, o no pueden parecérsele: los indios, negros y mestizos, los pobres y casi todas las mujeres de todas las razas.

La trilogía demuestra que América es otra cosa y algo más que una prolongación de Europa, y en tanto ese hecho se silencie desde el poder político y económico, el continente seguirá desconociéndose, ignorándose, despreciándose, no siendo más que una mutilación dolorosa de sí mismo: "El elitismo, el racismo, el machismo y el militarismo impiden que América reconozca en el espejo su rostro múltiple y luminoso". ${ }^{2}$

La obra presenta toda la vida en suelo americano, desde la creación de la primera mujer y el primer hombre según la mitología de los makiritare, hasta las postrimerías de nuestro "siglo del viento". Como toda versión de la historia, opera selectivamente, interesadamente. ¿Acaso es posible escribir la historia "objetivamente"? ¿Acaso escribir no es necesariamente escribirse, leerse a sí mismo aquél que escribe, desde su propia circunstancia histórica?

Mdf no sólo es historia, también es poesía. El autor conmueve y convence no sólo gracias a su magistral manejo de la abundantísima información, sino a que argumenta sin tregua en el nivel estético de la recepción. Cada secuencia de $M d f$ constituye un texto independiente de prosa bella y vital. Toda creación artística es política porque toma partido frente a la realidad, y es proselitista porque busca conmover y convencer al receptor. También en $M d f$ Galeano practica la literatura para "ayudar a ver"[se] a sí mismo y a los demás, más allá de lo fácilmente visible en la era dominada por los medios de comunicación masivos; para "golpear" a los que se benefician de la ignorancia de las mayorías explotadas; y para "abrazar" a los que aman, como él, un futuro mejor, sin humillados. ${ }^{3}$ América Latina, las injusticias y mentiras que sobre ella dominan, son el pretexto de las publicaciones de Galeano, ${ }^{4}$ deseosas de una humanidad más feliz y menos enemiga de la naturaleza; sin "primer", "segundo" y "tercer" mundos, sino uno solo, habitable y digno para todos.

$M d f$ es un texto de historiología poética que se resiste a ser clasificada según los modelos usuales de géneros literarios. La trilogía reúne e interpreta los más variados documentos del pasado. Todo lo que se cuenta ha ocurrido en la realidad extraliteraria, aunque el autor lo cuenta a su "modo y manera", ${ }^{5}$ a partir de más de mil fuentes escritas citadas, que son de toda naturaleza: desde los estudios de sociología, antropología, economía, historia y arte en que se basa también la historiografía tradicional, hasta otros documentos, como cartas de

\footnotetext{
2 "Apuntes sobre la memoria y sobre el fuego".

3 "Apuntes sobre la memoria y sobre el fuego", en Brecha, Montevideo, 20 de abril de 1990.

4 Eduardo Galeano, Las venas abiertas de América Latina (1971); La canción de nosotros (1975); Dias y noches de amor y de guerra (1978); El libro de los abrazos (1989), entre otros.

${ }^{5}$ Eduardo Galeano, "Umbral" o prólogo a Los nacimientos.
} 
amor, manuales guerrilleros, libros y otras publicaciones sobre cualquier tema. Señalando la base documental de su texto, el autor busca asegurarse una recepción comprometida del mismo.

El narrador omnisciente de $M d f$ se desliza infatigable por el tiempo y el espacio con una cámara de video a cuestas, registrando cuán bella y terrible ha sido y es la vida en suelo americano, al norte y al sur. Nos asoma a observar "el universo a través del ojo de la cerradura", ${ }^{6}$ y a percibir a los que vivieron antes que nosotros como nuestros prójimos. A verlos y a oír sus voces, sus júbilos y terrores. Ese narrador-camarógrafo calla a veces para que las otras voces hablen: hay secuencias que son citas integras de terceros - canciones populares, avisos de prensa, pasajes de cartas o de alocuciones públicas. Pero ese narrador nunca se ausenta del texto: guía sin lamentos y con soltura, humor e ironía al lector a través de los subtítulos, registro de su respectiva posición en el tiempo y el espacio desde la cual publica, casi siempre en tiempo presente, los hechos generalmente narrados y a veces dramatizados en cada secuencia.

En 1492, desde la llegada de los europeos al "nuevo mundo", arranca en $M d f$ la concepción del tiempo tal como lo conocemos, y las secuencias se ordenan así cronológicamente. Las secuencias que presentan la historia a partir del Siglo XVI penetran en la raíz de los malentendidos individuales y colectivos que determinan el mundo que hoy habitamos, y ese mundo es mostrado feroz y maravilloso. Contar el pasado del continente con anterioridad a esa fecha, y a partir de las voces de los propios sujetos de ese pasado, es una tarea imposible. El autor lo sabe, pero acomete la escritura de esas Primeras voces con los únicos, inadecuados instrumentos de que dispone: la lengua española, que es la suya y está impregnada de la visión eurocéntrica del conquistador. Y los escasos, indirectos documentos que registran la cosmovisión preponderante en las culturas precolombinas en América. Aquí las secuencias se ordenan según el plan ontológico de la creación: personas, tiempo, estrellas, animales y plantas según los mitos de culturas que se nos mantienen inaccesibles. La primera parte de Los nacimientos, traducción de traducciones, constituye sin embargo un homenaje belloy valiente a la América que fue arrasada por el hombre blanco desde el siglo XV, cuando trajo consigo la codicia y afianzó definitivamente el poder del miedo. Memoria del fuego ha sido escrita contra la amnesia y la soledad. Conoce numerosas ediciones en diversas lenguas desde su aparición y fue distinguida en 1988 con el Premio de Literatura del Ministerio de Cultura del Uruguay, y en 1989 con el American Book Award de la Universidad de Washington/Seattle, en la versión traducida por Cedric Balfrage, editorial Pantheon.

RAQUEL GARCIA

${ }^{6}$ Eduardo Galeano, Dias y noches de amor y de guerra. 